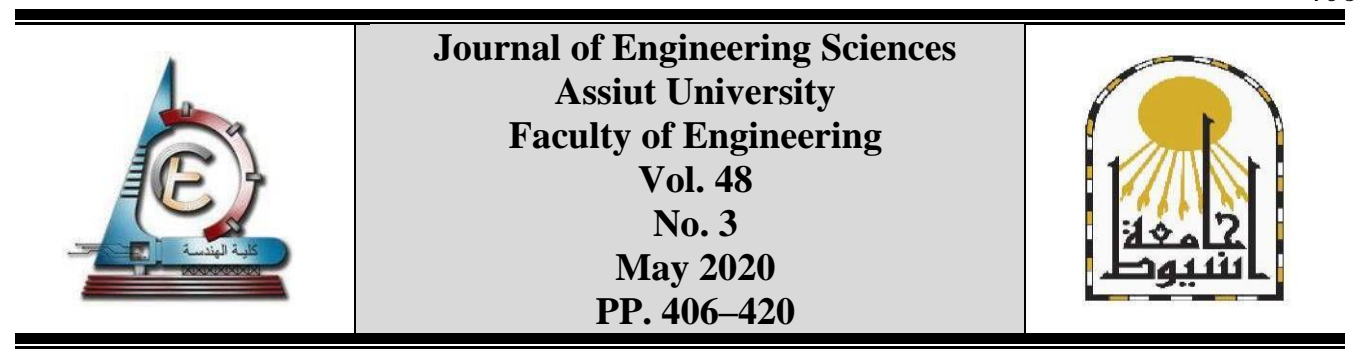

\title{
THE MINARET: A REASSESSMENT OF ARCHITECTURAL FUNCTION AND RELIGIOUS VALUE, IN LIGHT OF MODERN TECHNOLOGY
}

\author{
Hossam Mahmoud Massoud Mohamed
}

\author{
Ain Shams University, Faculty of Engineering
}

Received 1 December 2019; Accepted 17 December 2019

\begin{abstract}
This essay seeks to provide a theoretical discussion of the normative and juristic position with respect to building and using minarets in contemporary mosques. It provides arguments dealing with its function and purpose and the way mu'adhen should relate to it in light of current loudspeaker technology. The essay investigates relevant religious scripture and authoritative scholarly textbooks on the subject matter, in attempt to deduce the proper rulings of 'Fiqh' on basic issues pertaining to programming and designing a place for propagating adhan from the mosque. More fitting alternatives are proposed with general theoretical guidelines for architects and urban designers. The author concludes that traditional minarets are no longer needed in contemporary mosques, and that the expenses that they cost should be invested elsewhere. Loudspeaker Towers are far more practical and far less costly. The author also proposes a kiosk outside the mosque for the mu'adhen, since he argues that adhan should not be delivered from inside the mosque.

These findings are expected to challenge commonly held beliefs with respect to a minaret, and the author looks forward to rigorous and scholarly discussions on the matter.

\section{Introduction}

The Mosque is a religious building. Now, you would think that it takes its function and configuration of spaces exclusively from the teachings of the religion it serves. However, sadly this is not the case. Architects commonly resort to tradition and a received set of configurations that has been identified with mosques for ages. Although it's common sense that followers of a prophet are supposed to follow him, and only him, in the way they set up their houses of worship, one can easily argue that the mosques we build today are in violation of much of his teachings, صلى الله عليه وسلم. Naturally, times have changed, building materials have evolved, numbers of congregants have swelled, and so arose the dire need for more sophisticated structures and forms in construction of mosques, within of course - reasonable budgets. Obviously that cannot be avoided. It is dictated by the pressing demand of Masaleh Mursalah المصالح المرسلة as recognized in Sharee a. ${ }^{1}$
\end{abstract}

\footnotetext{
${ }^{1}$ According to A'mady, Masaleh Mursalah المصالح المرسلة are those religious benefits that have neither been established (by scripture or by analogy القياس nor dismissed. They only arise under novel demands and requirements that help with keeping and upholding religious duties حفظ الدين from time to time. They take credence from general Maquased (considerations) of Shari 'a' مقاصد الثريعة, c.f.: [1] \& [2]
} 
What troubles the author of this essay though, is the fact that Muslim architects generally know too little about the teachings of their religion in this respect, and are ultimately governed by a design and planning theory that takes its normative authority from historicity, traditionalism, and, of course, from contemporary architectural trends. A mosque should have a dome, because it would hardly look like a mosque if it did not. You may invent a new form for the dome that still 'feels' like one, but unless you're miserably challenged in your resources, you will probably have to go through some heated debate if you choose to omit it altogether in your design. It should have a Mihrab because, well, that's where the Imam traditionally stands. What would people say if they saw a blank wall where the mihrab is traditionally installed? It should have a minaret, because that is what we expect to see when we look at a mosque, right?

So what does religion actually have to say about all of this? In this essay, the author seeks, within the limited space available, to challenge the commonly held theory of design and planning for mosques in modern times, particularly with respect to the 'Minaret'. The validity of the belief that a mosque should always have at least one minaret, as long as the budget and space would allow it, will be examined juristically. Naturally, the author will presuppose the premise that when Muslim architects design an Islamic house of worship (a mosque), they should be bound by the rulings of Islamic Sharee a above all else.

\section{What is a Minaret?}

Briefly put, it is the 'Islamic Version' of the Church Tower. A Church tower is an elevated structure from whence the call for prayer (by whichever means) is sent out to the farthest possible reaches in town. In an article about the evolution of Minarets, Creswell [3] argues with confidence that the first minarets 'were derived architecturally from the Syrian Church tower'. He establishes that minarets where not even known in the Muslim world before the Umayyad Era, when the site of 'the great Temenos' (a Christian Basilica) in Damascus was converted by Al-Walid Ibn Abdul-Malik into 'The Great Umayyad Mosque' الجامع الأموي الكبير, turning the four square towers that it had left on its four corners, into minarets for Adhan. He also cites Al-Maqrizi's claim that Mu'aweya the disciple and king رضي الهه عنه ordered Maslama Ibn Makhlad (then Governor of Egypt) to build Sawami' at the four corners of the 'amr' mosque in Cairo for Adhan. Now while historians would not bother much to further investigate the authenticity of this claim by Al Maqruizi's about Mu'aweya, scholars of Hadith would not let it pass without scrutiny of Isnad إسناد (The sequence of narrators) which it probably lacks, leaving it unauthenticated. They would bother to scrutinize it as such, because if authenticated, someone might take it for religious evidence that a disciple actually decreed the construction of minarets.

Another account of the origins of the minaret comes from Al-Baladhori البلاذري the Iraqi historian, in his book 'Fotuh al Buldan' where he maintains that it was first constructed in Basra around $45 \mathrm{H}$ (665 AD) by Zeyad Bin Abih who was appointed governor by Mu'aweya. [4]

In any case, it remains historically indubitable that the minaret was not built by the prophet neither in the mosque nor outside, neither was it built or endorsed by the Khulafa' Al Rashidin (Righteous Khalifas) afterwards, despite the vast spread of the Caliphate in their rein, and that it was - at least - inspired by temple or church towers in Syria or in Iraq. 


\section{Deducing the religious ruling}

If indeed it is the case that neither the prophet صلى اله عليه وسلم nor the Righteous Khalifas constructed a minaret, or anything like one, in any of their vast spreading conquests, despite the fact that elevating the mu'adhin المؤذن (the person in charge of calling for prayer by adhan) for his voice to reach out, had always been a good idea ever since the first call of adhan in Medina, and despite the fact that it didn't take a genius to figure out that a Church tower or a 'Sawma'a' or something like it would be an obvious solution, then one has to wonder; why didn't they do it? If indeed a church tower could so easily be repurposed, or something similar to it could easily be built to do the job, then what kept them from doing it? Even the disciple 'Amr Ibn El'Ass رضـي الهه عنه evidently didn't have minarets built in the first mosque he constructed in Egypt (they were only added later on as cited earlier), despite his knowing very well that it was - then - the only mosque in the city, and despite the fact that his builders must've been well aware of the idea of a church tower, or of towers in general, so why didn't he?

Now it would be quite hasty to claim that the answer to this question is that they must've all believed it to be an unacceptable religious innovation to build such a tower, and that whenever that happened, whatever the circumstances, then they would rule it out as an imitation of Christian religious figures. We cannot make such a claim, because we know for a fact that when minarets were first built in or around mosques, none of the disciples or their followers was ever reported to have said anything against them. Apparently the first minarets were built quite early in the first century after Hijra. So if they found the very idea of dedicating a tower for the mu'adhen to rise above, religiously objectionable, we should have plenty of narrations and reports showing just that. Followers and students of disciples would have had quite a strong religious incentive to keep such reports for coming generations, having to witness that 'innovation' first hand, every time they went to a mosque. However, we have none.

So what exactly does the scripture say?

As it happens, we do have an age old agreement among Muslims since the time of the prophet صلى الله عليه وسلم and his companions that it is desirable for the mu'adhin to take all necessary measures within his power for his voice to reach as far as it should.

Perhaps the strongest evidence from scripture to support this agreement is the Hadith documented in Sahih Al Bukhary (n. 597) and in Sahih Muslim (n. 1092) that 'Abdullah Ibn 'Omar said that the prophet صلى اله عليه وسلم said (according to Muslim): "Bilal raises the Adhan at night, so eat and drink until Ibn Um Maktoom raises his adhan". To that the narrator (Ibn 'Omar) commented saying: "No sooner than one of them descends, the other ascends". ${ }^{2}$ This clearly shows that prayer was commonly called for from an elevated place. It does not, however, imply that the act of ascendance is particularly desirable as a general norm; neither does it tell us anything about the nature of the object that was ascended on.

This is to be inferred from another hadith. Disciple 'Urwah Ibnul Zubair narrated (as documented In Sunan Abi Dawood) that a woman from 'Bani Alnajar' said: "My house was the tallest around the mosque, so Bilal used to raise the adhan for Salatul Fajr (the Prayer of Dawn) from its top. He used to sit there looking at the sky until he detected the

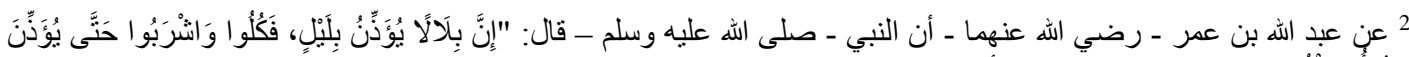

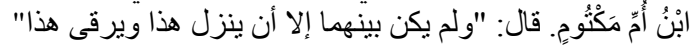


Hossam Mahmoud Massoud Mohamed, The minaret: a reassessment of architectural .........

break of dawn". ${ }^{3}$ Al-Albany [5] , authenticated the Hadith. This establishes that the act of ascending was to the top of the highest nearby building. Yet it also tells of an additional reason why the top of a building was selected. It made it easier for Bilal to sit there so he could detect dawn time by eyesight, where he would be clear from any visual blocks or distractions around, thereby correctly determine when to raise the adhan. Those are the only two authentic pieces of scripture on the matter.

So, it can be maintained at this point that ascending to the most elevated position near the mosque was needed for two general purposes:

- To send the sound of the adhan to as far as it has to reach in town.

- To detect dawn time visually for adhan Al-Fajr.

The author said 'as far as it has to reach' not 'as far as possible', because in a modern city where we have a multitude of mosques, the sound of one mu'adhen from one particular mosque could easily be made - using the technology of today - to reach to almost everywhere in the city. Yet, whether or not this 'has to be done' or 'needs to be done' is another question altogether.

In any case, we can establish at this point that the physical elevation of the mu'adhen is generally a matter of Maslaha Musrala (unfixed benefit or demand) مصلحة مرسلة. If his voice can easily be heard from the top of the mosque, then there need not be a towering minaret for him to call from. And indeed building one in that case should be considered a waste of funds, time and resources. If the adhan can be heard effectively when delivered by the gate of the mosque, then the mu'adhen doesn't even need to ascend above anything at all. This, I argue, is why the minaret was never built by the prophet himself صلى الله عليه وسلم or any of the Khulafa' AlRashidun. In Medina, at that era, raising the adhan from above the mosque or from the top of a higher neighboring building was quite enough. Only when the need arose, and the idea was suggested at a later time (The Umayyad kingdom), were those towers erected after all.

In his book "Al Madkhal", the Maleki scholar 'Ibnul Hajj' mentions three levels of physical location for the mu'adhen, favoring the minaret for better serving the demand of sound reach. He says [6]: 'It is of the Sunnah that the mu'adhen should do the adhan on top of the minaret. If that wasn't possible, then on top of the mosque, and if that wasn't possible then at the gate of the mosque.' This means that in his view, the sound of the mu'adhen should be sent out to as far around as possible. He holds that the minaret is indeed the sunnah of the Salaf (the disciples and their followers), saying: 'The minaret in the times of the Salaf, was a building constructed on top of the mosque, looking like it does today'. However, we've seen that there is no compelling evidence to support the claim that the minaret was part of the first mosques that were built by the prophet صلى الله عليه وسلم or any of his disciples, and that Bilal actually ascended to the top of a neighboring house, not on top of a dedicated tower above the mosque. Thus we cannot hold that the minaret, per se, in whatever way that it looks, is particularly favored in 'Sunnah'. What needs to be achieved is delivering the sound of the mu'adhen as needed. The question of 'how', though, is obviously a question of 'Maslaha Mursalah' مصلحة مرسلة.

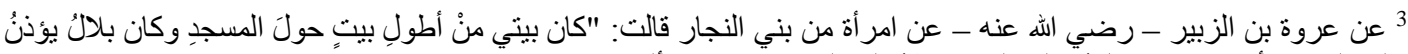

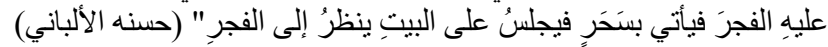


It may be worth mentioning that scholars of Fiqh, according to 'Ibnul Hajj', discussed the height of a minaret, and concurred that it should not be built so high that it would violate the privacy of neighboring houses (visually). If it was built after the houses, then its height should be considered accordingly. If, on the other hand, it was built prior to the houses, then it's the builders of the houses that should make sure not to place their windows in such a manner as to allow for the mu'adhen to accidentally invade their privacy from atop the minaret. Such considerations are obviously quite difficult to even try to uphold in today's city, if indeed minarets had people ascending them.

However, it is clear that in modern times, both purposes we outlined earlier can be fulfilled without the need for the Mu'adhen to physically stand on top of a tower, or even a higher building. The sound can be spread to whatever distance by means of loudspeakers that can be fixed anywhere, and wired (or even connected wirelessly) to wherever the mu'adhen is physically performing the adhan. As for the prayer times, all mosques are now following a highly accurate astronomical table of prayer times, where the mu'adhen only needs to follow his hand watch wherever he is, to know precisely when to call for prayer. So now, we have to address the question of the minaret as two separate issues rather than one:

- Do we still need to have a towering structure at all? And if so, what would be its function, and where should it be installed?

- Where should the mu'adhen stand while performing the adhan?

\section{Reconsidering the religious function and value of the minaret}

If indeed the entire purpose of a minaret is to farther the reach of the adhan in town by elevating the mu'adhen physically, then it is probably safe to say that we no longer need to do that. In his book "Al Ajuweba Al nafe'a", Imam Nasirul Din Al-Albany argues [7] that loudspeakers and sound amplifiers leave us in no need today to build minarets, especially given the fact that they cost a lot of money. He says that the fact that nobody ascends above them anymore, is enough evidence to prove that there's no longer an actual functional need for them in contemporary mosques.

Therefore, what needs to be designed for the purpose of propagating the adhan today is actually a proper configuration and distribution of loudspeakers in the area that houses those people who are served by the mosque, one that ensures that the sound would reach them adequately and comfortably. Massoud [8] deduced a mathematical formula to determine the area in question for neighborhood planning. If indeed it is decided by acoustic experts that an elevation of loudspeakers is needed for better acoustic performance in certain cases, then a dedicated tower may not be the only option. It may not even be the best option, given the considerably high construction cost that it takes to build a minaret, as pointed out earlier.

Perhaps the urban designer could consider making use of the light posts in the streets, or of the corner edges of certain buildings or billboard holders, to hang those loudspeakers in a functionally and aesthetically fulfilling manner. However, one needs to consider that if the sound of the adhan was propagated in town from a multitude of loudspeakers, then it would not be possible for any passerby (who's not familiar with the place) to follow the sound source in search for the mosque. It may be argued that this is an important function of the adhan, which may also explain why Bilal would typically ascend upon the mosque itself or a high roof somewhere in the vicinity. 
Yet this reasoning could be countered by the fact that when 'Othman decreed an additional adhan prior to Salatul Jum 'a, as documented in Sahih Al Bukhary (870), he ordered it be raised from a place in the main market in Medina called Al Zawra', which was nowhere in the vicinity of the mosque itself. This means, as may be argued, that the purpose of using the adhan as an acoustic guide to the place of the mosque was never really part - in Islamic Jurisprudence - of what Adhan is all about. But then again, that could be rebutted by the argument that Othman only did that with Salatul Jum 'aa for the purpose of reminding people at the market that the time for Jum'aa is almost in. It wasn't actually a call for the mosque, as is the case with the adhan for the five prayers of the day. This is why it is not to be raised - today - from the minarets of the mosque itself (as is the case in many mosques) since that is not what it was for.

However, the point about Bilal almost always raising adhan somewhere in the vicinity, can be defeated by arguing that this doesn't necessarily mean that adhan was deliberately raised at a point where people would be able to tell the direction of its source from a distance. It might be the case that he did that because he didn't want to have to travel for too long after he raised the adhan, risking missing part of the Salat himself. In other words, the location of the sound source had to be elevated for people's benefit, and it had to be close to the mosque for his own benefit as a mu'adhen. This can be supported by a hadith narrated in (Sunan Abi Dawod) where Bilal asks the prophet صلى الله عليه وسلم not to say 'Amen' before he can be there to say it too. This shows that he worried he might miss some part of the Salat, coming down from wherever he ascends to do the adhan. Yet the hadith was shown by Imam Albany [9] to be inauthentic. In any case, now that the mu'adhen no longer has to be at the urban sound source physically, then it no longer matters where exactly his voice emanates from. Besides, Bilal usually raised the adhan from over a neighboring building as shown above, so if this consideration was there, wouldn't it be confusing to some people following the source of the voice from a distance, to find it actually coming from a neighboring house, not from above the mosque itself?

Thus, the author maintains that urban designers and acoustics experts are in no obligation to design the distribution of loudspeakers in such a way as to make the mosque detectable as the sonic source of the adhan. It is possible, though, to design the loudspeaker towers with visual signs on each tower to tell people seeking them on the streets, which way to go to the mosque.
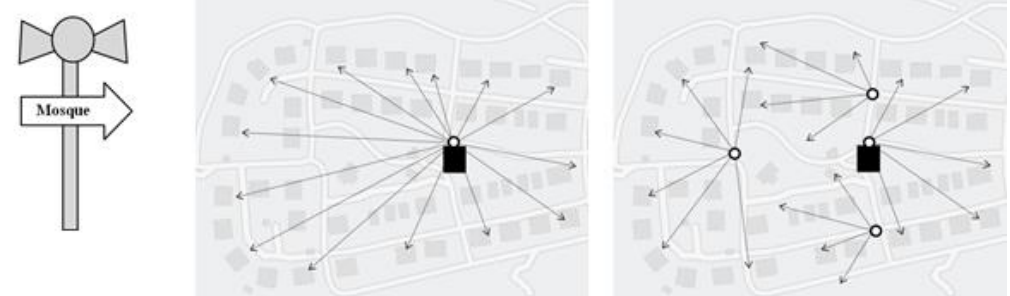

Fig. 1. (Left) Loudspeaker post, (Middle) Single Post distribution, (Right) Multiple Post Distribution (Source: Author)

Naturally, if it's only going to be one tower, then that tower should probably be set up somewhere near the mosque, preferably within its land. It should suffice to spread the sound in all directions around the mosque as desired [Figure 1]. Perhaps the case with multiple towers would make more sense if it were only dedicated to the weekly call of Salatul Jum'a, gathering people from all corners of the neighborhood to the central Jami' 
mosque المسـد الجـامع المركزي, whereas smaller mosques would each have its own loudspeaker tower covering its own smaller area of service.

The delivery of adhan, in this day and age, is not necessarily restricted to loudspeakers though. In addition to loudspeakers, further research is required to investigate more innovative ideas applying modern day technology for that end.

So what should become of the minaret then?

Well, whatever the case may be, we no longer need it to be a tower that allows a person to climb to its top to call for prayer from there. According to this reasoning, it is to be reduced to a loudspeaker tower. This means that it no longer needs to be made of anything more than iron, as is normally the case with light posts in urban streets. This does not, however, leave that simple tower devoid of any aesthetical value as some architects might worry. Yet, the author of this article supposes it is not aesthetics, per se, that most architects would complain about at this point, it is the 'iconic value' or the 'symbolic meaning' and other such cultural considerations that would trouble them in this conceptual reassessment. If indeed it's going to be no more than a loudspeaker post, if at all, then nothing would justify the amount of money it costs to make it look as toweringly high and bulky as it does. Donors who participate in giving Sadaqa (religious donations) to build a mosque should be advised (religiously) not to waste that money by putting it where it is needed the least. Muslim architects would have the religious duty to instruct them that using money to expand an existing mosque or even feed some hungry Muslims, rather than build an expensive minaret (as in common tradition), would be the right thing to do.

As for the question of cultural icons and symbols, a Muslim architect would do good to remember that religious icons and symbols are associated with other religions not with Islam. If Christian towers have crosses on top, that's because the cross is their religious icon. Muslims, on the other hand, don't take the crescent for a religious symbol, and they don't associate beliefs to it or to any other figure for that matter. So while we don't consider the idea of building a religious tower to be a characteristically non-Muslim concept, it's hard not to think of fixing a religious symbol on top of that tower as one. [10]

It could still be argued, though, that the notorious image of a towering minaret acts as a landmark that visually guides people to the mosque from a distance. Some minarets do in fact play that part in many mosques, especially in lager mosques where they would easily rise to over ten or fifteen meters high. We cannot deny that. Yet, we have to wonder, is this a sufficient justification for the amount of money that it would take to erect such huge towers the way people expect to see them, especially in those larger mosques where they do act as long distance landmarks? One has to consider that just two of such towers in a mosque like 'Masjid Al Nour' in 'Abbaseya, Cairo, for example (see Figure 1 below), might have cost enough money to build an entire mosque somewhere else. No matter who's donating that money; it's supposed to be spent in the greatest religious good, not to make one particular mosque look as monumental as the pyramids of Guiza. This is yet again another tradition that is alien to Islam, one that prophet Muhammad صلى الله عليهوسلم himself did in fact disavow in his time. Disciple Ibn 'Abbas narrates that prophet Muhammad صلى الله عليه وسلم 
had said: 'I was not commanded to plaster mosques', and comments: 'You will ornament it like Jews and Christians did'. 'Al-Albany authenticated the Hadith. [11]

Examples are given in a later section of this paper, of critically acclaimed mosques that did away with the minaret altogether, and yet managed to provide a distinctive visual character for the mosque that arguably sufficed in this respect, especially given the relatively dense urban fabric that modern cities are characterized by.
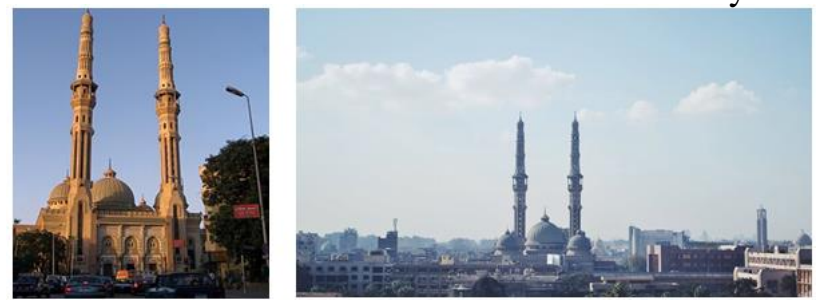

Fig. 2. Masjid Alnour [12] Fig. 3. Masjid Alnour [13]

The author, thus, argues that we do not need to turn a mosque into a towering monument for people to be able to find their way to it. Even if somehow the need arose in urban design for some feature of the mosque to be turned into a visual landmark, then it doesn't have to be such a mammoth of a tower. There is very little objective justification in paying that much money for the sake of making a minaret visible from such a great distance, or even for making it visible from any distance for that matter. This would qualify as a case of money waste that Islam teaches against.

\section{Reconsidering the location of the mu'adhen}

The next issue that needs to be addressed in this essay, is the question of where the mu'adhen should stand while performing the adhan, now that we've established that he no longer needs to be elevated physically. It's obviously an important question for architectural function, since the minaret was originally designed for him to ascend on, and since determining where he should be, would definitely affect the functional configuration of spaces and fixtures in the design of mosques.

Now, what's common in most of today's mosques is that the mu'adhen would stand where the mikes and the sound system are, and that's usually right next to the 'minbar' and the 'mihrab' where the imam performs the Salat. However, there is sufficient religious evidence to argue that this is not where he should stand. As for scripture, we've already shown that the mu'adhen at the times of the Sahaba (disciples) and their followers was never located inside of the mosque. It is obvious that if calling for Salat is what adhan is about, then it's meaningless to do it inside the mosque, since it's the people outside that you're calling unto, not the ones who are already there. The mu'adhen has no business troubling those doing Salat or reading Quran inside the mosque with the adhan. Scholars of Shari'aa actually held that argument against the innovation by Hisham Ibn 'Abdel Malik (in the second Hijri century) where he got the mua'dhen to do the Jum'aa adhan right next to the minbar, rather than from the minaret outside, which is probably why most muadhens still do it there to this day, in addition of course to the convenient location of the mike, as pointed out earlier. ([2], [6], [7])

4 عن عبد الله بن عباس رضي الله عنهما قال: قال رسول اله صلى الله عليه وسلم: "مـا أمرت بتشييد المسـاجد"، قـال ابن عباس: لتزخرفنها كما زخرفت اليهود و والنصارى. 
Some may object at this point, arguing that since the loudspeakers now do the job of propagating the sound, then there is no reason to place the mu'adhen outside. However this would be true, if indeed the arguer could show that the mu'adhen was originally supposed to stand inside while calling for prayer, and that only because of the limited reach of his voice, did he have to go outside. Yet we can see that no such evidence could be provided. In fact we've just shown that the exact opposite was the case, as in scholars' denunciation of Hisham's innovation. So the mu'adhen should always do the adhan outside of the mosque, regardless of how far his voice would reach.

Imam Al-Albany even goes a bit further (2000) arguing that the very idea of people outside being able to observe the mu'adhen as he raises the adhan, is itself part of the Sunnah that needs to be revived and observed. However, unlike the religious demand for the mua'dhen's voice to be heard, the claim that his sight is also required to be seen calls for particular evidence, which we don't seem to have. He does, however, make a good point when he says that placing the mu'adhen outside with a mike at his disposal, has the benefit of his voice continuing to reach the ears of many people, even in cases where the electric power would blackout amid the adhan.

In all cases, the author argues that Muslim architects are required to design a shaded stand outside the mosque for the mu'adhen, with a fixed mike. This shed could either be attached to, or detached from the mosque, depending on the available land around the mosque. Detachment is preferable, since it will make it more discernible that the mu'adhen is actually doing adhan outside of the mosque, and perhaps decrease the inconvenience that the sound of the adhan would cause to people inside the mosque itself. If possible, it is also preferable to have more than one loudspeaker tower distributed around the mosque facing away from it, and as distant from it as possible, to further insure that the sound of the adhan does not trouble people inside the mosque, since, as elaborated earlier, this is one of the considerations that scholars of Fiqh had in mind when they judged Hesham Ibn 'AbdelMalik's relocation of mu'adhen to inside the mosque as a religious innovation.

Now, since it is unlikely that the mu'adhen would keenly take the trouble to ascend on top of the mosque, knowing that he can always use the mike from ground level, we find it unrealistic to design that shed on top of the mosque with a stair leading to it from inside, as suggested by Imam Al Albany (2000). The idea of maintaining sound propagation even in the rare cases when the power is out at the time of the adhan, is not enough to convince any mu'adhen to have to go through the trouble of ascending the stairs five times a day every day.

Besides, if indeed there is a power outage, then given the nature of the contemporary city and the towering concrete buildings that would probably be surrounding any mosque in town quite densely, it probably won't make any difference where the mu'adhen stands with respect to the mosque anyway, if he were to use his own unamplified voice in adhan. At least on the ground, more passersby in the street where he stands, and perhaps quite a few of those in the ground floor in immediately neighbouring buildings, might be able to hear him better than if he were to call from above the mosque. This situation calls, of course, for investigation by acoustics experts in every case on its own.

[Figure 4] to the left, shows a concept sketch of the attached kiosk or shed that this essay proposes designing for the mu'adhen to perform adhan outside of the mosque at all prayer times. The mu'adhen should get out a couple of minutes before adhan time, stand in place, facing qibla, 
and call in the mike, regardless of where the loudspeakers are fixed around the mosque. In case of attached kiosks, the entire space could be enclosed with glass for his convenience.

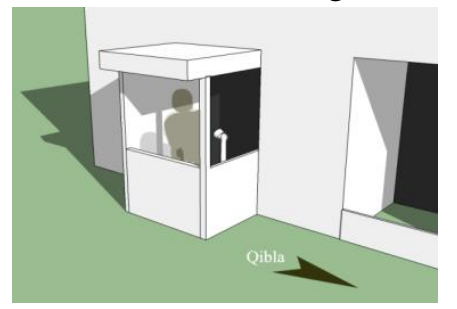

Fig. 4. Mu'adhen Kiosk, Concept Sketch (Source: Author)

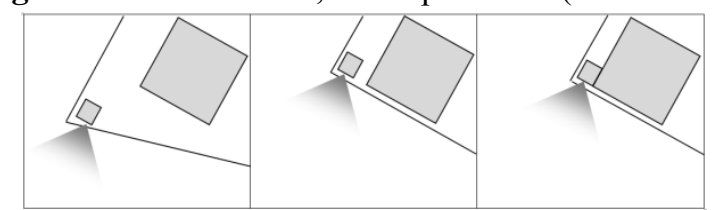

Fig. 5. Mu'adhen Kiosk; the farther away (within dedicated land) from the mosque and its entrance the better (Source: Author)

\section{Examples of modern Minaret Free mosques}

The idea of designing a mosque without a minaret is by no means a novel idea. Some lay people and even professional architects have already been going that way for different reasons. It looks like many have started to realize that designing tall minaret towers for mosques is no longer a functional practice or economically plausible. UK based architect, Shahed Saleem, who won the Aga Khan Award for 2016, designed a mosque in London in 2013 with no minaret or dome. He exhibits pride in his design of the Shahporan Masjid and Islamic Centre Trust on Hackney Road (Fig. 6) precisely because of this. He thinks that it would be fake and wasteful to design a towering minaret when in fact a UK mosque no longer needs one or uses it in any way. [14] He also believes that this modern approach would better express the identity of British Muslims in our times, as people who hold on to their religious heritage while responding positively to the challenges brought about by urban modernity.
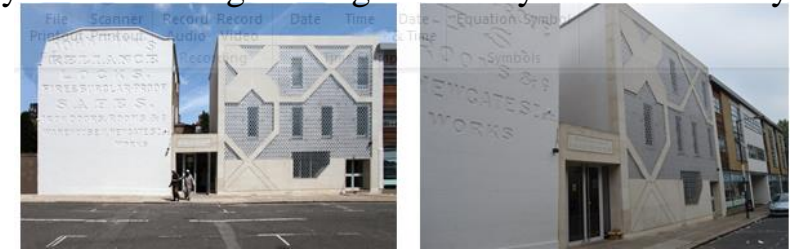

Fig. 6. Shahporan Masjid and Islamic Centre on Hackney Road, London (Source: [14], [15])

The mosque is composed of two buildings, one that used to be an old warehouse for a safeworks company, and another that is designed as a concrete cube with a veil (metal mesh) of traditional fretwork ornament screening the windows in 'mahrabeya' style, inspired by a $13^{\text {th }}$ century Anatolian tile [18]. Besides this traditional ornament and the sign above the gateway, it would be impossible to tell that this is indeed a mosque. Yet the Agha-Khan architect still thought this was quite enough.

It should be noted at this point, that broadcasting adhan in loudspeakers is prohibited in this district, as is the case with the majority of districts in the UK. The mua'dhen only raises the adhan with his own unamplified voice, standing at the gate of the mosque. So the question of how to deliver the adhan loud enough to cover the entire district, was never addressed by western mosque designers because they seldom ever had that opportunity. 
Consequently, the loss of function of the minaret has become far more pronounced and characteristic of mosques in western cities than here in the Middle East.

Moreover, it seems that it's not just functionality that is in question here; the traditional visual message is also being reconsidered. Saleem explains that: 'meshing new forms with the past is significant in his work, to maintain the connection with Islamic history, architecture, and culture, but by using it in a way that is contemporary. It's about using it in a new way for its own purposes and situation' [14] He says to Buzzfeed News: 'We do have to generate our own architectural language which reflects our European Muslim identity.' [16]
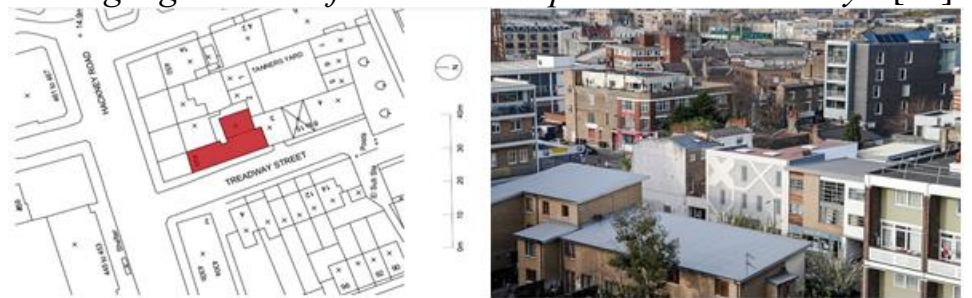

Fig. 7. Shahporan Masjid blends in the cityscape and fits squarely in its context (Source: [17])

An even smaller and more modest example of a minaret free mosque is the Bishops Way community centre in London. The building literally looks like a small hut in the suburbs of London. The only traditional image that could help people identify the mosque, visually, besides the sign above the gate, is a logo that abstracts the traditional form of a mosque, spelling the name of the mosque (Dar Assalam), a symbol that can hardly be seen a couple of meters away from the building.
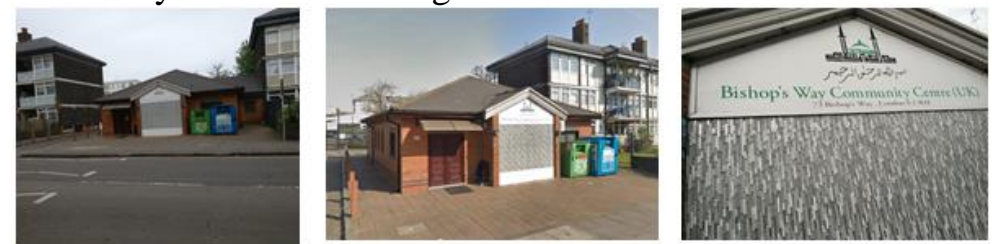

Fig. 8. Bishops Way Islamic centre hardly looks like a religious building (Source: [19])

One local example can be found in the centre of the 'Muhimmat Neighbourhood' in Nasr City, Cairo, originally designed and built in the eighties by the Armed Forces to be sold in subsidized prices to military officers and their families. 'Al Nour' mosques are designed with no minarets, and with a sloped skylight that takes the place of the traditional dome (see Fig 9). The Adhan is delivered from two loudspeaker posts, 3.5 meters high each, one set up near the outer wall with the main entrance, and the other back near the skylight, with two speakers on each post, facing opposite to each other (Fig. 10).

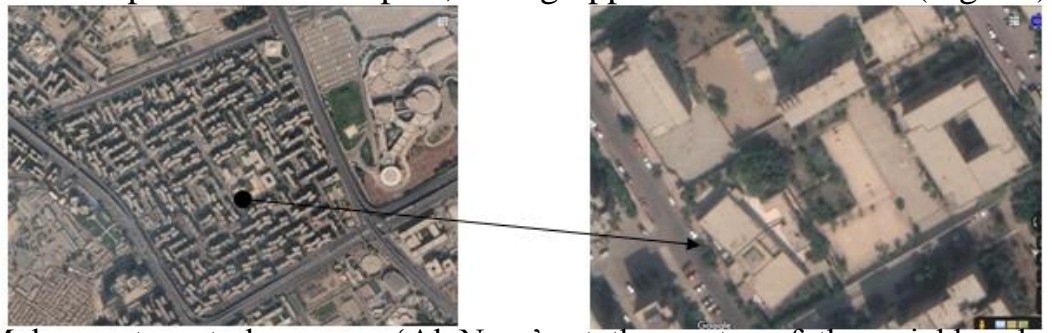

Fig 9. Muhemmat central mosque 'Al Nour', at the centre of the neighbourhood (Source: Google Earth Satellite image)

As a resident in the neighbourhood, the author can say from personal experience that the posts are doing a more than enough job in delivering the sound of the adhan to all the 
surrounding blocks and housing clusters, and that despite other mosques raising the adhan quite loudly from other locations within the neighbourhood (mostly near the perimeter as in Fig. 9), the sound of these speakers can be heard even in local streets around those mosques. At the northern corner of the neighbourhood, lies the renowned 'Al Rashdan' mosque.
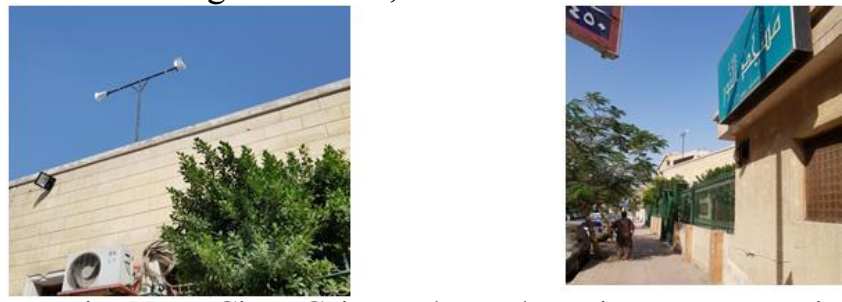

Fig. 10. A mosque in Nasr City, Cairo, where the minaret was omitted, in favour of a loudspeaker post. (Source: Author)

As for the visual character of the mosque, a pedestrian walking on the main street that hosts the main entrance to the mosque, generally finds no difficulty in telling that there's a mosque there. Given the way that the neighbourhood centre is designed, the mosque enjoys a vast space surrounding it from all directions. The windows, designed in walls that are characteristically shifted towards Qibla, have 'arabesque' work adorning them, 'mashrabeya style', along with a simple line of ornament encircling each window.

The speaker posts themselves are also tell tale signs that this is indeed a mosque, although it has been argued in this essay that they need not be set up that high, or even on posts at all. It is not clear to the author why the speakers were made to face in those particular directions, or why they were separated, at the top of the post, by that distance.
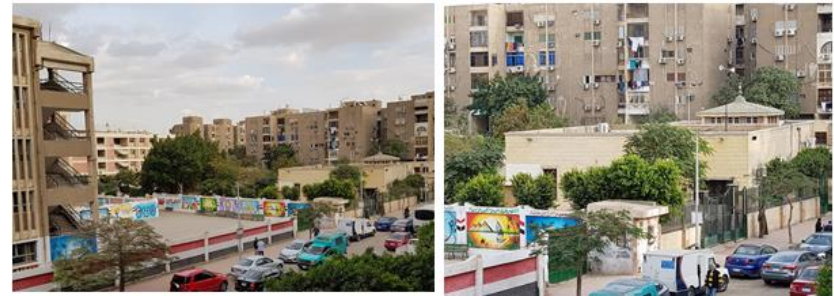

Fig. 11. Muhimmat central mosque 'Al Nour’ (Source: Author)

Figure 12 shows yet more uncharacteristic designs, that look even less like a mosque. It seems pretty obvious that the designers of these mosques are trying too hard to blend in with the city, in fear of social and political pressure. The Globe Town mosque in London to the left looks more like a minimart, or an airlines company office, than a mosque. You wouldn't even know what signs to read, in order to identify it if you're looking for it. The 'Baitul Mamur Academy mosque' to the right, identifies itself as a mosque by means of a logo showing a dome and a minaret on its sign. It is almost like saying: 'This is what we wish we could like like, if we had more power'.
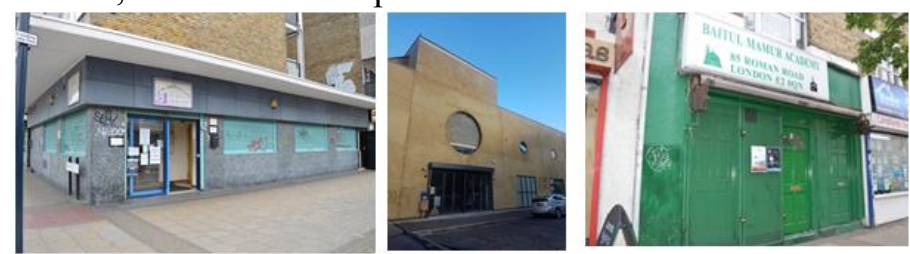

Fig. 12. From left to right: The Globe Town mosque, London - Baitul Aman mosque, Bethanl Green, London - Baitul Mamur Academy mosque, Bethanl Green, London (Source: [15]) 
This unsettling phenomenon in western mosque design brings forth an important and more general question in Architectural Theory: Is it a problem for a mosque to look like something else, or in other words, to look nothing like mosques are traditionally expected to look like? In terms of religious ruling, there is no particular form or shape or cast that architects are required to mold their mosque facades into. Yet the mosque is definitely the most important public facility in the city, so we need to be able to identify it by means of some level of visual contrast with the rest of the context that surrounds it, at least so we wouldn't need to read signs to find it, or to ask around in search for it. But how do we do that? Does a mosque need to encompass certain motifs or traditional elements (like the minaret) in its facade, so that people could identify it as a mosque?

Those are questions that demand a more thorough investigation in Mosque facade design, for which an entire essay is to be dedicated.

\section{Conclusion and Recommendations}

In this essay, we've argued in favour of the following contentions:

- Minarets, or anything like them, were never built by the prophet صلى الله عليه وسلم or by Khulafa' Rashidun, because they were never needed, given the general urban form of Medina at the time (the first half of the first Hijri Century).

- If, indeed, a towering structure is not needed to propagate the adhan effectively enough, then building it would be a waste of resources, and it is prohibited to waste money and time in Islam.

- The idea of a metallic crescent fixed on top of the minaret or the dome, and the entire notion of a religious symbol or religious icon, is alien to Islam, so architects are advised to refrain from it.

- In order to propagate the adhan, the mu'adhen is not required to ascend physically anymore. Outdoor Loudspeakers could (and should) be designed on urban posts as needed, while he calls in the mike.

- Loudspeakers should be configured and distributed in town in such a way as to cover the area of influence or the service area of the mosque effectively, without making it too loud (uncomfortable) for some of the residents.

- To reduce noise inside the mosque; the farther away we place the loudspeakers from the mosque and its entrance, the better. Multiple loudspeaker towers may better be dedicated for the weekly call to Salatul Jum'a in the large mosque at the center of the neighborhood, whereas other smaller mosques could use their own towers, one for each.

- While a multitude of loudspeaker towers in town calling for the same mosque would tarnish people's ability to follow it aurally, a system of urban signs properly designed on those towers themselves and elsewhere would easily make up for that, perhaps even do a better job at it.

- The mua'dhen is not supposed to do adhan from inside the mosque, since he's not supposed to be addressing the people inside. And since he no longer needs to ascend physically anywhere, this article proposes building him a special kiosk or small shed where he would raise the adhan in time in the mike. 
- The kiosk should be as far away from the mosque or at least from its entrance as possible, within the land dedicated for the mosque, so that his call would be positively addressed to the outside not to the inside, with as little noise inside as possible.

Further research is recommended

- in the areas of acoustics and urban design,

- to examine other more advanced technological options than loudspeakers.

- To study the question of contextual design and contrast in the composition of mosque facades, in attempt to create a distinctive visual character for the mosque without the use of a towering minaret, or much of the traditional motifs that used to be identified with mosques in the past.

\section{REFERENCES}

[1] Al'Amadi, Al Ihkam fi Osoul Al Ahkam, Volume 3, (KSA: Darel 'Usaimi)

[2] Al Shawkani, A. M., Al 'E' etesam, (KSA: Dar Ibn 'Affan)

[3] Creswell, K. A. C., "The Evolution of the Minaret, with Special Reference to Egypt", The Burlington Magazine for Connoisseurs, Vol. 48 No. 276: 137-140, 139

[4] Al Baladhori, Fotuh Al Buldan

[5] Al Albany, M. N., Sahih Sunan Abi Dawod., (Kuwait: Gheras Foundation, 2002)

[6] Ibnul Hajj, Al Madkhal, Vol. 2, (Cairo: Maktabet Darel Turath), 241

[7] Al Albany, M. N., Al Ajweba Al nafe' a' 'an As'elat lajnatil Jame'a. (Riyadh: Maktabatul Ma aref, 2000)

[8] Massoud, H. M., "The Urban Centrality of the mosque and the concept of neighborhood unit", Engineering Research Journal, Vol.1 No. 36 (2018), 124-132

[9] Al Albany, M. N., Da'eef Sunan Abi Dawod, (Riyadh: Darul Ma'aref, 1989), 937

[10] C.f. Ibn 'Othaimin, M. S., Majmou' Fatawa Ibn 'Othaimin, (Riyadh: Darel Thuraya, 2002)

[11] Al Albany, Sahih Sunan Abi Dawod

[12] Wikipedia article on Alnour Mosque https://ar.wikipedia.org/wiki/(القاهرة)_(Accessed 18 May 2019)

[13] Flickr Hive Mind page showing Alnour Mosque https://hiveminer.com/Tags/mosque\%2C النور (Accessed 18 May 2019)

[14] Asharq Al-Awsat Online Magazine, Nov. 23, 2016, 'British Architect Designs Mosques without Minaret, Dome'

https://eng-archive.aawsat.com/theaawsat/features/british-architect-designs-mosqueswithout-minaret-dome (Accessed 9 December 2019)

[15] British Towerhamplet Mosques Website, https://www.towerhamletsmosques.co.uk/shahporanmasjid/ (Accessed 9 December 2019) (Accessed 9 December 2019)

[16] Ummah Sonic Online Magazine (2016) 'Shahed Saleem is shaking up Mosque design' https://ummahsonic.com/shahed-saleem-shaking-mosque-design/ (Accessed 9 December 2019)

[17] Archnet Online Magazine, https://archnet.org/sites/16018/media_contents/116764 (Accessed 9 December 2019)

[18] INews Online Report, March 2018, 'What Britain's beautiful mosques teach us about our shared history'

https://inews.co.uk/news/long-reads/british-mosque-architecture-design-history-shahedsaleem-325948 (Accessed 9 December 2019)

[19] Bishops Way Islamic Community Center Official Facebook page, https://www.facebook.com/Bishopswaycommunitycentre/ (Accessed 9 December 2019) 


\section{المئنة: إعادة تقييم للوظيفة المعمارية والقيمة الدينية، في ضوء التكنولوجيا العصرية}

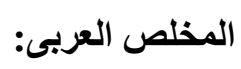

يحاول هذا البحث أن يقدم مناقثة نظرية للموقف المعياري والثرعي المتعين اتخاذه بإز اء بناء واستعمال المنائر

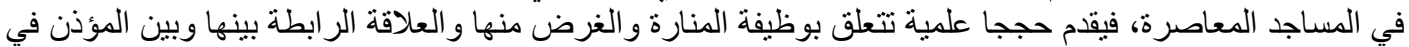

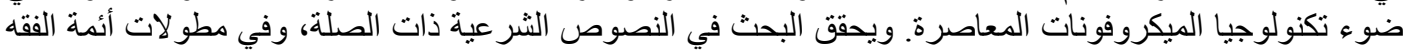

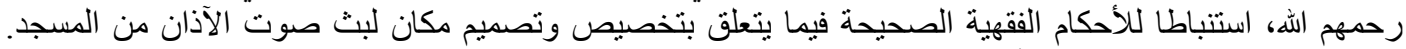

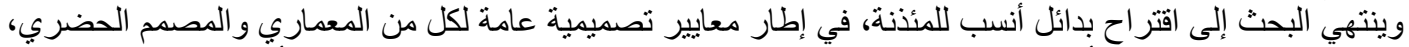

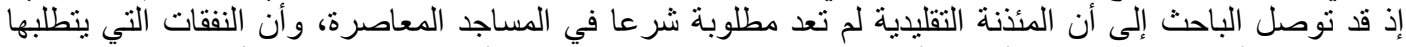

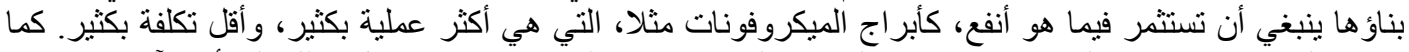

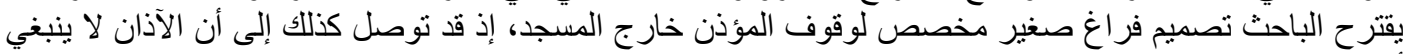
أن يرفع من داخل المصلى.

ويتوقع لهذه النتائج أن تشكل تحديا للاعتقادات السائدة فيما يتعلق بالمئذنة، ويتطلع الباحث لمناقتة علمية بناءة فيما

يتعلق بتلك القضية. 